DOI https://doi.org/10.18551/rjoas.2020-10.19

\title{
EMPOWERMENT OF MARKETING ASPECTS IN INCREASING ORGANIC RICE FARMERS' INCOME IN SAWANGAN, MAGELANG, CENTRAL JAVA OF INDONESIA
}

\author{
Setiawati Atik*, Wijaya Mahendra, Setyowati Retno \\ Department of Community Development, Faculty of Postgraduation, \\ University of Sebelas Maret, Indonesia \\ *E-mail: atiksetiawati13@gmail.com
}

\begin{abstract}
Organic agricultural products' prospect is getting better, indicated by the increasing demand for organic rice and relatively higher prices. This is an opportunity to increase the income of organic rice farmers. However, in reality, not all organic rice farmers in Sawangan Subdistrict experienced this increase in revenue. Organic rice marketing still follows the old tradition of selling unhulled rice to intermediaries, so farmers' bargaining position is weak. The Sawangan Organic Rice Farmers Association, as a forum for organic rice farmers, has a role in empowering through the marketing aspect of organic rice products. How is the process of empowering the Sawangan Organic Rice Farmers Association's marketing aspects, and the impact of empowerment on farmers is a research question. This study uses a qualitative research approach with data collection methods through observation techniques, in-depth interviews, and documentation. The research informants were determined by purposive sampling and maximum variation sampling. The data validity was done by triangulation technique with data collection instruments from data sources. The research found that the Organic Rice Farmers Association empowered the marketing aspects through the awareness process, capacity building, and empowerment. The empowerment process has an impact on increasing income for organic rice farmers. Farmers can also meet the clothing, food, shelter, health, and education needs of family members. Farmers manifest a high spiritual attitude by giving alms as an expression of gratitude to God Almighty for the provision provided.
\end{abstract}

\section{KEY WORDS}

Empowerment, marketing, association, organic rice farmers, sawangan.

Organic agriculture, as a provider of healthy food, has received significant attention from various countries in the world. The importance of healthy living habits is increasingly being realized by residents in both developed and developing countries. Indonesia is one of the states that has implemented organic agriculture. One of the largest organic rice agricultural producers in Indonesia is Magelang Regency, Central Java Province. The area of organic rice farming in the Magelang Regency is 1,150 Ha spread over five sub-districts. Sawangan is a sub-district with the largest organic rice farming area in Magelang Regency. The area of organic farming in Sawangan Subdistrict reaches 600 hectares with the leading commodity of organic rice.

Organic farming has high prospects. The heightened prospect of organic agriculture is in line with the increasing demand for organic products and relatively higher non-organic rice prices. This prospect is an opportunity for farmers to increase their income. In fact, not all farmers feel this way. Farmers earn income from selling organic rice at various prices. Organic rice farmers in Sawangan District also felt this. Farmers who sell organic rice to intermediaries receive the same price as non-organic rice. According to Mayrowani (2012), organic products' marketing still refers to market prices in general if farmers do not have a special market for organic agricultural products. This puts organic rice farmers in a weak position.

The conditions that are not in favor of the farmers require solutions and support from various parties. A farmer institution's existence supports organic farming in Sawangan District as a facilitator in empowering organic rice marketing aspects. The Sawangan Organic Rice Farmers Association was formed to carry out its role as a farmer institution that can 
change the condition of organic farmers to become more empowered, independent, and prosperous.

\section{LITERATURE REVIEW}

Empowerment is an effort to provide strength to the beneficiary community. Improving the quality of human life physically, mentally, economically, and socio-culture in the direction of empowerment (Mardikanto, 2013).

According to Wirihatnolo and Dwidjowijoto (2007), community empowerment activities consist of three stages, that are:

- Awareness stage by providing motivation and enlightenment so that the target can get out of the problem;

- The capacitating stage through individual capacitance, organizational capacity building, and value system capacity building;

- The step of providing resources by giving trust to the beneficiary community to apply skills in managing their resources.

Korten (1984) states that in empowerment activities, the concept of people-centered development prioritizes community participation in the empowerment process and makes spiritual material welfare a development goal.

Marketing is one of the essential aspects of agricultural empowerment activities. Marketing is the process of exchanging products, services, and values from a person or group to others in meeting their needs (Putri, 2017). Marketing in agriculture is a process that starts from offering input, selling raw material products, intermediate products, and final products from producers to consumers (Anindita, et. al., 2017: 4-5).

\section{METHODS OF RESEARCH}

Research on Empowerment of Marketing Aspects in Increasing Organic Rice Farmers' Income uses a qualitative descriptive method with a case study approach. This study uses the triangulation of data sources. Data collection techniques are observation, in-depth interviews, and documentation. The determination of informants in this study was carried out using purposive sampling and maximum variation sampling techniques. The informants are the Chairman of the Sawangan Organic Rice Farmers Association, organic rice farmers, and the Association of Farmers Groups. This study's data analysis technique is based on Miles \& Huberman (in Sugiyono, 2015), which consists of data reduction, data presentation, concluding, and verification.

\section{RESULTS AND DISCUSSION}

Before being formed the Sawangan Organic Rice Farmers Association, organic rice farmers in Sawangan District sold their harvested unhulled rice to intermediaries using a slash system. The marketing of unhulled rice to intermediaries is carried out because no farmer institution can accommodate large-scale organic rice yields. After establishing and inauguring the Sawangan, Organic Rice Farmers Association in 2013, organic rice marketing management gradually began to change. Farmers sell organic rice to the Sawangan Organic Rice Farmers Association.

Based on the research results, the empowerment process carried out by the Sawangan Organic Rice Farmers Association refers to the opinion of Wrihatnolo and Dwijowijoto (2007). This opinion states that community empowerment is carried out through a process of awareness, capacity building, and empowerment. The empowerment process carried out by the Sawangan Organic Rice Farmers Association are:

Awareness process. The socialization is the first step of empowerment carried out by the Sawangan Organic Rice Farmers Association for organic rice farmers. The socialization activity provided information to establish the Sawangan Organic Rice Farmers Association in the marketing aspect of organic rice products. The socialization also provided information 
and understanding of the transparent marketing system for organic rice products carried out by the Sawangan Organic Rice Farmers Association. In a sale and purchase transaction, the grain is weighed first to determine the amount of grain; then, a payment is made based on the grain's quality at a relatively higher price. With a scale system, farmers know the amount of product and their cost in real terms. This sales system is different from the slash system, which determines payments based on production estimates. Thus, farmers do not know the actual production and income. The Sawangan Organic Rice Farmers Association also provides an overview of a religious aspect. Selling unhulled rice with a weighing system, farmers can pick organic rice and do alms at harvest time by increasing rice pickers' wages. Almsgiving will bring blessings to farmers.

The information and understanding of the Sawangan Organic Rice Farmers Association's sales system are slowly changing farmers' views. Farmers are slowly starting to switch by selling their grain on a scale to the Sawangan Organic Rice Farmers Association. It was stated by the Chairman of the Sawangan Organic Rice Farmers Association: "Previously, we had socialization about the organization. We will convey the meeting time with farmers, Gapoktan, and Farmer Groups. We give a simple understanding of the slash system and weighing. The results are cut down; the results are estimated, so farmers do not know how much the actual yield is. If we sell unhulled rice to Gatos, the system is weighed, the result is a higher price. So the farmer's income increases. We are changing this mindset slowly. I also conveyed that if the sale of unhulled rice was weighed, farmers could harvest their grain and give alms by giving additional harvest wages. It will bring blessings to the farm." (Interview with Mr. Ahmad Saleh, 3 March 2020).

Mr. Ahmad Saleh's statement was strengthened by the opinion of the Chairman of the Association of Farmer Groups (Gapoktan) Tani Mulyo': "In the past, the farmers here sold their rice, bought their crops by the small village traders. The person who buys the harvest already knows how to estimate the harvest yield to assess rice from the land, but the farmers don't know how much their product is. So if you pick it yourself, you weigh it, the farmers know that my harvest is like this. If it is sold to Gatos, the price is higher than the price on the market. Every time the Gapoktan meeting is here, we convey information like that, thank God, now organic farmers are selling them to Gatos " (Interview with Mr. Tarman Wiyoto, 12 June 2020).

The Capacity Building Process. The capacitating process carried out by the Sawangan Organic Rice Farmers Association consists of:

1. Farmer capacity building. The Sawangan Organic Rice Farmers Association provides market information and post-harvest handling to build capacity for farmers. Types of rice varieties that are of interest to consumers, the price of an organic rice grain and organic rice marketing are market information provided to farmers. The Sawangan Organic Rice Farmers Association recommends farmers to plant rice varieties in great demand by the market, namely mentik wangi susu, IR 64 , brown rice, and black rice. Organic rice paddy owned by farmers will be purchased at a relatively higher price than the market's available price. Besides, the higher cost of organic rice is an opportunity for farmers to increase their income. This is because people are increasingly aware of the importance of maintaining health by consuming organic food.

Apart from market information, the Sawangan Organic Rice Farmers Association also provides information on post-harvest handling to farmers. Information on post-harvest handling has not been carried out intensively through training activities during group meetings.

"Every group meeting, we tell the farmers about the market. After harvesting, we have also said that only the practice in the group is not yet. We suggest to farmers who want to grow organic rice; it has to be according to market needs, mentik wangi susu, the icon is Sawangan, IR 64, brown rice, and black rice. We also say that the price of organic rice is high; we also buy the grain at a high price according to quality. Farmers are already delicious. The market for organic rice is now increasing because the mindset of buyers has changed. Whatever price he buys because he wants to be healthy, this is an opportunity for farmers" (Interview with Mr. Ahmad Saleh, 3 March 2020). 
The Sawangan Organic Rice Farmers Association has a market development program by increasing organic rice production capacity. Efforts to support the program are carried out by encouraging farmers to become entrepreneurs in organic rice businesses. Through this effort, farmers can be more creative and innovative by taking advantage of market opportunities.

The market development program was initiated in June 2020 through post-harvest handling guidance to prospective business actors. Post-harvest handling guidance includes storage, drying, milling, grading, sorting, and packaging activities. This guidance aims to obtain the quality of rice following the Sawangan Organic Rice Farmers Association's quality standards: "We always invite farmers if they want to join the business, please because if they are a business actor, their mindset will go forward, but not all can because the risks are massive. We have a future program that will develop the market; we continue to encourage farmers to become business actors. This June, I am guiding organic rice farmers to join in rice marketing. I am teaching this again to process rice so that the quality is according to our specifications. We teach them from drying, cleaning, grading, sorting to packaging" (Interview with Mr. Ahmad Saleh, 10 June 2020).

The statement of the Chairman of the Sawangan Organic Rice Farmers Association was supported by the Chairman of the Association of Farmer Groups 'Tani Mulyo': "There are always invitations for business from Gatos ... but not all farmers can because it takes time, requires capital, and knowledge. So farmers who want to join the rice business are allowed. There is guidance from Gatos' friends. Guided for drying because the water content is also determined, rice's water level is around $14 \%$. If you want to grind it, then join it with Gatos. Later, the whole rice is separated from the groats, and the black rice is separated; there are many steps, so the quality is good" (Interview with Mr. Tarman Wiyoto, 12 June 2020).

2. Organizational capacity building. The Sawangan Organic Rice Farmers Association conducts organizational capacity building by changing its management. Since the Sawangan Organic Rice Farmers Association's establishment, the management change has been carried out twice, namely in 2015 and 2019. The management change aims to realize the Sawangan Organic Rice Farmers Association, which is increasingly advanced and developing. This is done by making a program plan as follows:

- Conduct training to improve the quality of human resources, especially in postharvest handling and marketing;

- Increase production capacity to develop markets by encouraging the growth of organic rice producers in several areas in Sawangan District;

- Diversify processed products from organic rice;

- Carry out independent exports.

It is based on the results of an interview with the Chairman of the Sawangan Organic Rice Farmers Association: "At the beginning of the formation, the organization was called Tani Organik Sawangan (TOS). In 2015 we reorganized from the Sawangan Organic Farmers (TOS) to the Sawangan Organic Farmers Association (GATOS). The organizational structure has also changed. In 2019 we had a second reorganization; it's only the organizational structure that has changed. The hope is that this organization will be more advanced. Our future program is market development, export, training from cultivation to marketing, and processed food from organic rice" (Interview with Mr. Ahmad Saleh, 3 March 2020).

3. Value system capacity building. The Sawangan Organic Rice Farmers Association has regulations on Standard Operating Procedures (SOP), which are made based on mutual agreement and must be adhered to by all members. The Standard Operating Procedures (SOP) are:

- Purchasing grain from farmers must refer to the Approved Farmer List (AFL) data;

- The quality of organic rice must comply with the standards of the Sawangan Organic Rice Farmers Association; 
- Organic rice marketing is carried out one door on behalf of the Sawangan Organic Rice Farmers Association;

- The purchase price of unhulled rice and selling rice must be based on the Sawangan Organic Rice Farmers Association provisions;

- Business actors must contribute to the Sawangan Organic Rice Farmers Association by providing a fee of Rp. 200 for every sale, $1 \mathrm{~kg}$ of organic rice. The contribution is used for land certification costs and operational costs for the Sawangan Organic Rice Farmers Association.

This is based on the results of an interview with Mr. Ahmad Saleh, Chairman of the Sawangan Organic Rice Farmers Association: "Who wants to join the business, please. The market can follow us, but the SOP must also follow us because we have standards to maintain quality. So, the purchase of grain must be following the list of farmers in Gatos, onestop marketing on behalf of Gatos. Quality, and price must also match our standards. It can't be different. Entrepreneurs must give the organization a fee in the form of money, deducted by $\mathrm{Rp} .200$ per sale of $1 \mathrm{~kg}$ of rice. The money is for certification costs and operational costs for Gatos" (Interview with Mr. Ahmad Saleh, 3 March 2020).

Powering Process. The Sawangan Organic Rice Farmers Association carried out the provision of power by buying organic farmers' grain. The relatively higher price is one way the Organic Rice Farmers Association motivates farmers to implement organic rice farming consistently. Another form of empowerment effort is to provide technical guidance for the post-harvest handling of organic rice. Advice is given to increase farmers' capacity as potential business actors in producing quality products.

Based on an interview with the Chairman of the Sawangan Organic Rice Farmers Association: "We buy rice from these farmers at a high price, but it depends on the quality of the grain, whether it is good or not. We still have a standard minimum price to farmers. Even higher than the price on the market. So farmers still have more. If the farmers want to join our business, it's also open, go ahead. Anyone can. Later we will guide the post-harvest. After we suggest the quality follows the specifications, we let it go, meaning that we are no longer recommending it. The market follows Gatos, but we still have to follow our existing SOP." (Interview with Mr. Ahmad Saleh, 3 March 2020)

The statement of the Chairman of the Sawangan Organic Rice Farmers Association was strengthened by the opinion of the Chairman of the Association of Farmer Groups 'Tani Mulyo': "Farmers who want to join the business can also go to Gatos. You can also sell it yourself, only the brand and quality standards still follow Gatos. Besides, Gatos must also provide compensation, per kilo, if I'm not mistaken, Rp. 200." (Interview with Mr. Tarman Wiyoto, 12 June 2020).

The impact of empowerment on the marketing aspects by the Sawangan Organic Rice Farmers Association for farmers is:

1. Increased Income of Organic Rice Farmers. The Sawangan Organic Rice Farmers Association provides market opportunities for organic rice farmers by buying organic rice products from farmers. The grain from farmers is purchased between Rp. 4,500 to Rp. 7,000 per kg Harvested Dry Grain (HDG) according to the type of variety and grain quality. The cost of Mentik Wangi Susu grain is between Rp. 5,000 to Rp. 6,000. Red rice grain Rp. 4,600 to $\mathrm{Rp.} 5,000$. Black rice grains are Rp. 7,000, while IR 64 rice grains are Rp. 4,500 to Rp. 5,000. In December 2019, the Sawangan Organic Rice Farmers Association purchased the Mentik Wangi Susu variety for Rp. 5,500 per kg of Harvested Dry Grain (HDG). At that time, the market price for unhulled rice ranged from Rp. 5,200 to $\mathrm{Rp} \mathrm{5,300.} \mathrm{This} \mathrm{price} \mathrm{difference}$ illustrates the difference between Rp. 200 and Rp. 300. which has an impact on increasing the income of organic rice farmers.

The average amount of organic rice production obtained by farmers for the varieties of Mentik Wangi Susu, IR 64, and Brown rice is five quintals per $1000 \mathrm{~m}^{2}$, while for Black rice 23 quintals. Farmers who own tenants with an average production of 5 quintals and a grain price of Rp. 4,500 earn Rp. 2,250,000. The farmer earns Rp. 1,125,000. This income is obtained when farmers cultivate their fields with their labor. Farmers' income with other people's labor is Rp. $1,525,000$ to Rp. $1,910,000$. The income of the resident farmer is Rp. 
762,000 . This income is deducted by the harvest cost (bawon wage 1:10) of Rp. 225,000 and a maximum production cost of Rp. 500,000. Apart from the cost of harvesting and production costs, the costs incurred by the farmer are also shared with the rice field owner. The production sharing cost between farmers and rice owners is 50\% (maro system).

The sale with the slash system provides additional income for farmers. The price obtained by farmers by selling the slash system is Rp. 1,200,000. For farmers with this income, production costs and land rental costs still have to be deducted, so that the income they receive is low.

2. Meet the Basic Needs of Farmers. The income of organic rice farmers can meet the family's basic needs, including clothing, food, shelter, health, and education.

- Clothing needs. Farmers and their families can meet their clothing needs by providing clothes for family members;

- Food needs. Farmers can meet food needs, incredibly healthy rice. Rice is obtained by setting aside the grain from organic rice cultivation. Organic paddy rice is processed into rice for daily consumption so that farmers do not buy rice;

- Needs a board. The farmer has a suitable place to live with good floors, roofs, and walls. Besides, farmers also have motorized vehicles as a means of transportation to support activities outside the home. On the other hand, farmers can set aside the proceeds from selling organic rice grain to save money;

- Health. Farmers take care of the health of their family members by taking several measures. The action taken by the farmer if a family member is mildly ill is buying medicine at a pharmacy. If a sick family member requires medical treatment, he or she is taken to a health facility. These health facilities are village midwives, puskesmas, or hospitals;

- Education. Farmers can provide education for family members, especially children. At least the farmer's children take basic knowledge according to the government program. Currently, the children of farmers are carrying out instruction in Elementary Schools (SD), Junior High Schools (SLTP), and Senior High Schools (SLTA). They carry out knowledge in public schools, Islamic boarding schools, and private schools. Besides, farmers also provide opportunities for family members to gain religious knowledge by attending recitation.

This is based on the results of an interview with the Chair of the Sawangan Organic Rice Farmers Association as follows: "The impact on farmers is welfare. There is an increase in income. If a rice field area of $1000 \mathrm{~m}^{2}$ (1 keso) gets five quintals of unhulled rice, the price of rice for Rp. 4500 is already Rp. 2,250,000. If you ask someone to work on the fields, Rp 225,000 is deducted from the working capital; the maximum working capital is Rp. 500,000 , the get is between Rp. 1,525,000 to Rp. 1,910,000. Cultivators are still divided into two for land lease; they get Rp. 762,000.00. If you cut one keso, you can get Rp. 1,200,000. The result is divided into two (maro), he gets Rp.600,000. while the capital is Rp.500,000.00, the total net is only Rp.100,000. So there is a difference; the farmer's income increases." (Interview with Mr. Ahmad Saleh, 3 March 2020).

Based on the interviews with farmers, there is a difference in the price difference given by the Sawangan Organic Rice Farmers Association. The difference in price makes farmers' incomes relatively higher. The tenant owners conveyed this during the interview: "If it is a question of whether or not the proceeds from selling organic rice are sufficient. I want it to be more, but if you look at the market, there is a difference of Rp. 100, Rp. 200 per kg. Alhamdulillah, it is enough for me. Enough or not, it depends on each of us personally. The most important thing is that if I make school fees for the children the same for daily expenses, I'm grateful. As for my daily needs, I don't buy rice from the 1.5 keso rice field to feed myself until I harvest again. I usually sell the yield from 1.5 so again. The money he sells is for his daily needs. Suppose someone is sick at home, usually to the village midwife, later if there is a referral from the midwife, yes. In that case, we will follow the referral to the Public health center or the hospital, at least that's sister." (Interview with Mr. Budi Setyawan, 7 March 2020). 
A farmer owner and an owner conveyed the same thing: "So far, sales of unhulled rice to Gatos have a difference in the price of The difference is around Rp. 100 to Rp. 300 per kg compared to the price in baskets (traders). I sometimes get Rp. 1,800,000, but it doesn't depend on the harvest and the price. If I am grateful, for example, one keso can be Rp. $1,800,000$, thank God, it is sufficient for the family's daily needs. The need is clear for the cost of schooling children at the Islamic boarding school in Klaten the same for savings if it requires large expenses. If someone is sick, take him for treatment, like yesterday the father was ill, I would take him to the Public health center." (Interview with Mr. Sunarto, 9 March 2020).

A farmer conveyed the same opinion with a statement: "The price of Gatos is still high from the local market. So even though the rice yield is small, the price is higher. Just be grateful if I, because selling to Gatos, has many conveniences, it has helped. The proceeds from rice of sale are for children's schools for their daily needs. I don't buy rice, set it aside from the harvest. If the red rice plant is sold, everything will be exchanged for food. Another decision, yes, if Eid, buy children's clothes. If someone is sick, it is best to purchase medicine at the pharmacy if the pain is mild. Go to the Public health center or the hospital if there is a referral. But alhamdulillah, all this time is healthy. The other needs are, at most, water fees, RT activity fees. " (interview with Mr. Suhadi, 12 March 2020)

The statement of the Chairman of the Sawangan Organic Rice Farmers Association and farmers was strengthened by the opinion of the Chairman of the Association of Farmer Groups (Gapoktan) 'Tani Mulyo': "Farmers can prosper, miss, we can calculate it. The costs incurred by farmers to cultivate organic matter is at most Rp. 500,000. If the farmers' yields, say five quintals of unhulled rice, rice is $\mathrm{Rp}$. 4,500 or 4,600 per $\mathrm{kg}$; the farmers get Rp. $2,250,000$ to Rp. $2,300,000$. The money is still deducted by the cost of processing the fields and the harvest people; the farmers can earn around Rp. 1,525,000 to Rp. 1,575,000. If we take the lowest price, so if the price is high, the farmer's income will also be higher. The price was not cut that much, sister, even lower because it was just an estimate, not sure. With the increase in yields and the selling price of organic rice, farmers can automatically meet their needs. " (interview with Mr. Tarman Wiyoto, 12 June 2020).

The marketing empowerment carried out by the Sawangan Organic Rice Farmers Association to organic rice farmers has a considerable impact. The impact of marketing empowerment is an increase in farmer income. Besides, farmers can also meet basic needs, namely clothing, food, shelter, health, and education. The ability to fulfill these basic needs is following the skills of each farmer. This is because the income earned by each farmer is different. Based on the results of interviews with farmers, regardless of the income they make, it is sufficient or does not depend on each individual. Another thing that is considered more important by farmers is gratitude to God Almighty for the sustenance provided by performing worship and giving alms.

\section{CONCLUSION}

The marketing empowerment carried out by the Sawangan Organic Rice Farmers Association consists of a process of awareness, capacity building, and empowerment. The empowerment process impacts increasing farmer income and the ability to meet farmer family members' basic needs. Organic rice farmers have a high spiritual attitude by giving alms an expression of gratitude to God Almighty for the sustenance provided.

\section{REFERENCES}

1. Anindita, R \& Balladina N. 2017. Marketing of Agricultural Products. CV. Andi Offset. Yogyakarta.

2. Korten, David C. 1984. People-Centered Development. Kumarian Press. West Harford

3. Mardikanto, T. 2013. Community Empowerment by Companies. UPT Publishing and Printing UNS (UNS Press). Surakarta. 
4. Mayrowani, H. 2012. Development of Organic Agriculture in Indonesia. Agro-Economic Research Forum. Vol. 30, No. 2, pp. 91 - 108.

5. Putri BRT. 2017. Marketing Management. Udayana University. Denpasar.

6. Sugiyono. 2015. Combination Research Methods (Mixed Methods). CV Alfabeta. Bandung.

7. Sutopo. 2006. Qualitative Research Methodology Basic Theory and Its Application in Research. Sebelas Maret University. Surakarta.

8. Wrihatnolo \& Dwidjowijoto. 2007. Empowerment Management: An Introduction and Guide to Community Empowerment. PT Elex Media Komputindo. Jakarta. 